\title{
Refugees or Immigrants - How Does it Matter for Entrepreneurship? Systematic Review of Refugee Entrepreneurship Literature Inspired by the Immigrant Entrepreneurship Research
}

\author{
Nina Lazarczyk-Bilal
}

\begin{abstract}
Summary
This literature review answers the research question of how being a refugee or an immigrant affects entrepreneurial experience. It aims to examine the differences between refugees and immigrants in the light of immigrant entrepreneurship literature and emerging refugee entrepreneurship research. The analysis of the selected 41 peer reviewed papers within the framework of the eight dominant theories in immigrant entrepreneurship literature, including the field pertaining to refugees, implies that being a refugee has a rather negative impact on the entrepreneurial experience as compared to being an immigrant. Nonetheless, the literature on refugee entrepreneurship or their general labor market integration is rather scarce in number of applied theories and conducted studies in comparison to the immigrant entrepreneurship area and leaves vast room for future research.
\end{abstract}

Keywords: Immigrant entrepreneurship, Refugee entrepreneurship, Refugee labor market integration, Small business

JEL: L26, F22, O15, J15

\section{INTRODUCTION}

The number of forcibly displaced people around the world has reached 68,5 mln people (UNHCR 2018), which is more than the whole population of France. Out of $68,5 \mathrm{mln}$, about $40 \mathrm{mln}$ people are internally displaced migrants - those who have had to leave their home due to various reasons, but have stayed within the borders of their country. About 25,4 million people worldwide are refugees (UNHCR 2018) - people who have fled their country because of war or persecution. In 2015, about 1255600 refugees from Asia and northern Africa managed to cross the borders of the European Union. Since it is only the beginning of huge migrations, the EU member states have to look for adequate solutions in order to help accommodate as many newcomers as possible. Needless to say, refugees, often traumatized, have to settle down in a completely new socio-cultural and economic context. They need to find an apartment, learn the local language, adapt to the new culture and most importantly support themselves financially. Only after the massive influx of Asians and Africans to the $\mathrm{EU}$, the need to integrate so many refugees into local labor markets has drawn much more scholarly attention to the refugee entrepreneurship research. This research is still rather new territory for academics who can be immensely inspired by the vast body of literature on immigrant entrepreneurship.

I hereby address the research question: How does being a refugee or an immigrant affect one's entrepreneurial experience? In other words, I would like to examine the difference between those who were forced to flee their home country due to war or the fear of persecution and those who voluntary moved to another country in the light of entrepreneurship. This paper aims to present a systematic literature review on refugee entrepreneurship in the context of immigrant entrepreneurship. It is divided into five sections. In the following section I present the search process conducted in Scopus, one of the biggest abstract and citation databases of peer-reviewed literature and its results related

\footnotetext{
Faculty of Management, University of Warsaw, Poland, https://orcid.org/0000-0003-4020-027X, e-mail: lazarczyk.nina@ gmail.com
} 
to refugee and immigrant entrepreneurship literature. In the third part, I present the general concept of immigrant entrepreneurship and explain the terms "refugee" and "immigrant". In chapter four, I discuss similarities and differences between refugees and immigrants in light of entrepreneurship and the general labor market integration literature. I analyze those similarities and differences using the dominant theoretical frameworks within the immigrant entrepreneurship research. Finally, I present conclusions and limitations, which may serve as a source of inspiration for future research in the refugee entrepreneurship field.

\section{LITERATURE SEARCH METHODOLOGY}

In order to find the peer-reviewed articles on refugee entrepreneurship, I used the Scopus electronic database where I restricted the search to three subject areas (social sciences; business, management and accounting; economics, econometrics), articles and articles in press, peer-reviewed journals and English language. First, I defined the following search stream (refugee* OR asylum-seeker* W/6 entrepr* OR "small business" OR "self*employ*" OR "economic adaptation" OR "labo*r integration" OR "labo*r market" OR "career adaptability"), which returned 145 papers. I sorted the obtained results according to the number of highest citations. After an initial review I have selected 50 articles, and after further scrutiny I have decided to discuss in detail 19 papers which I find relevant for the topic. Most importantly, only 6 papers related directly to the topic of refugee entrepreneurship, whereas others concerned refugee labor market integration.

Having realized that the literature devoted solely to refugees or asylum-seekers is scarce, I have decided to try another set of key words focusing on immigrant entrepreneurship (*migrant* OR ethnic* W/6 entrepr* OR "small business" OR "self*employ*" OR "economic adaptation" OR "labo*r integration"). The search stream restricted to the same criteria as the previous one returned 1,670 articles. Once again I sorted them according to the highest number of citations. After an initial revision I chose 117 papers, and eventually decided to concentrate on 22 articles in this review.

In total, I have analyzed in detail 41 papers, which date from 1986 to 2018. Studies conducted in the selected papers examine the phenomenon of immigrant/refugee entrepreneurship or broader labor market integration in the US (18), the Netherlands (6), the UK (4), Norway (3), Canada (2), Belgium (2), Sweden (1), Denmark (1), EU (1), Australia (1), Turkey (1), Ghana (1) and Lebanon (1). Most of the selected papers focus on North America, Europe and Australia; whereas only 2 papers concern Africa and Asia and both of them analyze the phenomenon of refugee entrepreneurship. Within refugee related papers, 9 studies adopted a quantitative method, 8 studies used qualitative method, 1 study applied mixed method approach and 1 paper was a policy review.

In the following section I first explain the concept of immigrant entrepreneurship; secondly, I discuss the terms "refugee" and "immigrant" and signal basic differences between refugees and immigrants, which are likely to impact their entrepreneurship experience or general labor market integration.

\section{REFUGEE OR IMMIGRANT ENTREPRENEURSHIP?}

Among scholars there is no consensus on what entrepreneurship is, but most often the body of literature of our interest defines it as self-employment, start of one's own business or further development of an already existing company (Fong, Busch, Armour, Heffron, \& Chanmugam, 2008). Setting up and running one's own company in a new country is not an easy task, especially for immigrants or refugees who need to get familiar with the new system. Research implies that, since migration per se is an act of courage that already proves an entrepreneurial attitude, immigrants or refugees should be more likely to start their own venture (Bizri, 2017). Indeed, the substantial 
part of research indicates that immigrants become entrepreneurs proportionately more often than natives in the host countries (Bizri, 2017; Dheer, 2018). This is why many academics consider the phenomenon of immigrant entrepreneurship to be a separate research area (R. C. Kloosterman, 2003; Ley, 2006; Portes, Haller, \& Guarnizo, 2002a; Sahin, Nijkamp, \& Stough, 2011; Waldinger, 1989). However, the refugee entrepreneurship literature has not yet become a distinct research field, but has rather stayed a part of the broader literature on immigrants. This is quite surprising if one takes into account the history of refugee regime and the special legal status of refugees regulated in the 1951 Convention Relating to the Status of Refugees, the so called Refugee Convention. The convention defines a refugee as a person who has a "well-founded fear of persecution for reasons of race, religion, nationality, membership of a particular social group or political opinion, is outside the country of his nationality and is unable or, owing to such fear, is unwilling to avail himself of the protection of that country; or who, not having a nationality and being outside the country of his former habitual residence as a result of such events, is unable or, owing to such fear, is unwilling to return to it" (1951 Convention Relating to the Status of Refugees).

While the concept of the term "refugee" has been legally defined, the term "immigrant" does not have a single straightforward meaning and requires further definition depending on the context. On the one hand, it constitutes a very broad category of all the people who move from one country to another with an intention to settle down there. On the other hand, it often implies that migrants leave their country on a voluntary basis in order to improve their living standards, whereas refugees are forced to flee because of the fear of persecution (Gold, 1988, 1992). Consequently, immigrants have the opportunity to plan their life in a new country, for example bringing with them some start-up capital to set up a small business in the host country, whereas refugees do not have the ability to prepare for refuge, and thus do not possess any extra funds to start a business (Gold, 1988). Nevertheless, the recent influx of asylum-seekers to the EU has shown that refugees also plan their journey to Europe and save substantial sums of money to pay smugglers for their transit to the EU through the Mediterranean. Research shows that longdistance mobility requires sufficient resources, which can be organized by relatively well off people who have a certain social and financial situation (Omata, 2017). This is also one of the reasons why scholars acknowledge that making a clear distinction between voluntary and forced migration becomes problematic nowadays (Omata, 2017; Waite, 2017). Although drawing a stark line between voluntary and forced migration seems to be ambivalent, it is still possible to identify several general differences between refugees and immigrants (Gold, 1992; Wauters \& Lambrecht, 2006b). In the following chapter I will discuss the similarities and differences between refugees and immigrants in the context of the dominant theories within immigrant and refugee entrepreneurship literature.

\section{REFUGEES OR IMMIGRANTS: HOW DOES IT MATTER FOR ENTREPRENEURSHIP?}

Immigrant entrepreneurship has become a well developed research area contrary to refugee entrepreneurship, which is extremely poor in terms of theoretical frameworks and conducted studies (Alrawadieh et al., 2019; Bizri, 2017; Ruiz \& Vargas-Silva, 2017; Wauters \& Lambrecht, 2008). The immigrant entrepreneurship literature offers many theories as to why immigrants set up their own businesses in the host country. Some of these theoretical frameworks have been used either directly or indirectly in the literature on refugee labor market integration or refugee entrepreneurship. Below, I will compare refugees and immigrants discussing the dominant perspectives used in the immigrant entrepreneurship and refugee entrepreneurship research: human capital theory, social capital theory, culture theory, disadvantage theory, social network theory, transnationalism, interactive model of ethnic entrepreneurship and mixed embeddedness. 


\section{Human capital and Social capital theory}

The most basic explanations of immigrant entrepreneurship relate to human capital or social capital theory. The human capital theory helps to understand entrepreneurial experience by investigating individual characteristics, educational background, skills etc. immigrants have gained on their own, either back home or in a host country (Vinogradov \& Kolvereid, 2007). In other words, such factors as age, gender, household composition, number of years of formal education, previous job experience, or language proficiency determine labor market integration (Bach \& Carroll-Seguin, 1986; Potocky-Tripodi, 2004). For instance, findings from Belgium indicate that male refugees who have entrepreneurial role models in the family and have been previously self-employed are much more likely to become entrepreneurs (Wauters \& Lambrecht, 2006b). The social capital theory goes beyond personal characteristics focusing on the non-material goods in the immigrant community such as for example trust or helpfulness, which play an important role in undertaking entrepreneurial activities (Timothy Bates, 1997; Tomothy Bates, 1994; Deakins, Ishaq, Smallbone, Whittam, \& Wyper, 2007; Sahin et al., 2011). Similarly, a study based on ecology theory indicates that individual features, family relations and counseling play an important role in refugee entrepreneurship (Fong et al., 2008).

\section{Culture theory}

Since immigrants constitute a big and diverse group of people, many researchers argue that cultural differences between them explain why some migrants are more likely to start business activity than others. There is a substantial body of research on immigrant entrepreneurship inspired by Hofstede's five cultural dimensions (power distance, individualism versus collectivism, masculinity versus femininity, uncertainty avoidance, and long or short-term orientation) which explains the entrepreneurial attitude between different groups of migrants (Chand \& Ghorbani, 2011; Frederking, 2004; Li, 2001a; Vinogradov \& Kolvereid, 2007). For example, cultural approach argues that some cultures like for example Jews, Chinese or Japanese are more prone to start a business venture, however, in case of refugees it helps to understand only the choices of refugees who deliberately start their own company despite having promising job offers in the market (Gold, 1988). In short, the cultural perspective does not explain well the entrepreneurial activities of refugees who decide to set up their own business as a last resort to make money for a living (Gold, 1988).

\section{Disadvantage theory}

Disadvantage theory argues that since immigrants have lower job prospects due to being at a disadvantaged position in the labor market in comparison to the host society, and for this reason decide to open a small business (Gold, 1988). Their inferior position in the job market usually stems from language barriers, lack of locally recognized skills, lack of adequate qualifications, complex bureaucracy, or discrimination. The disadvantage perspective is very helpful in understanding decisions of both immigrants and refugees who set up business activity. In the following sections I will discuss further similarities and differences between immigrant and refugee entrepreneurs using the disadvantage framework. First, in light of the entrepreneurship perspective, I will examine similarities between immigrants and refugees who face language problems, do not possess necessary diplomas, are usually overwhelmed by bureaucracy in the host country, and fall victim to discrimination. Secondly, I will analyze the differences between immigrants and refugees focusing on legal and economic status, mobility aspects and the likelihood of psychological trauma. 


\section{Similarities between refugee and immigrant entrepreneurs in the light of disadvantage theory}

Disadvantage theory argues that immigrants who are usually worse off at the start in comparison to the host society members decide to open their own company as a last resort to make money in order to make a living. Nonetheless, it is not an easy process since they face such obstacles as language barriers and lack of locally recognized qualifications (Li, 2001a; Raijman \& Tienda, 2000). Similarly, language barriers, lack of recognized skills and high uncertainty about the future are faced by refugees who enter the entrepreneurial pathway (Alrawadieh, Karayilan, \& Cetin, 2019; Colic-Peisker \& Tilbury, 2006; Wauters \& Lambrecht, 2006b). Additionally, lack of funds, overwhelming bureaucracy, and lack of belief in one's own entrepreneurial potential are much more often mentioned by refugees than immigrants as obstacles to start business activity (Connor, 2019; Wauters \& Lambrecht, 2006b). Broadly speaking, these factors hinder refugees' access not only to entrepreneurship, but to the labor market in general (Bucken-Knapp, Fakih, \& Spehar, 2019). Last but not least, both refugees and immigrants suffer from discrimination in the job market, which results in either difficulties in finding a job or lower income (Alrawadieh et al., 2018a; Bucken-Knapp et al., 2019; Li, 2001b; Minor \& Cameo, 2018; Raijman \& Tienda, 2000). For example, a study conducted in the US shows that the latter concerns particularly refugees from subSaharan Africa, Latin America, and the Caribbean as well as female migrants or refugees (Minor \& Cameo, 2018).

\section{Differences between refugee and immigrant entrepreneurs in the light of disadvantage theory}

The legal status, which entails other consequences for refugee rights in the host country, is the most important differentiating factor between the refugees and immigrants. In the host countries, which are signatories to the 1951 Geneva Convention, refugees who either apply for asylum or have been already granted asylum have a different legal status from immigrants who are dependent on visa regimen, and thus the future of their stay is usually less secure. Refugees become asylum-seekers from the moment they apply for asylum in a host country signatory to the Geneva Convention, which entails legal consequences regulating many aspects of their stay in a country of arrival such as work permit, job training opportunities, economic status as well as freedom of mobility.

One of the significant issues for newly arrived refugees is the possibility to get employed as fast as possible and make money for living expenses. According to Article 17 of the Refugee Convention, the basic human right to work should be granted to those who are legally recognized as refugees. Depending on the host country newcomers usually have to wait for work permit for several months or longer, which negatively affects their future career, and makes their everyday life much less predictable. Research shows that refugees have a worse start in their job career in comparison to immigrants due to the long asylum procedure, and thus longer unemployment period (Bakker, Dagevos, \& Engbersen, 2017). The disadvantaged situation of refugees in relation to both immigrants and natives has its own name in the literature, namely the 'refugee entry effect' or the 'refugee gap'(Bakker et al., 2017; Dustmann, Fasani, Frattini, Minale, \& Schonberg, 2017). Research carried out in the Netherlands and the EU indicates that only after 15 to 20 years the 'refugee gap' ceases to exist or gets much smaller in relation to immigrants (Bakker et al., 2017; Dustmann et al., 2017). Other research findings from the United Kingdom show that 8 and 15 months from the successful end of asylum procedure refugees are still at a disadvantaged position in the job market in comparison to immigrants, while after 21 months the employment situation of refugees improves and does not differ significantly from the one of recent immigrants (Ruiz \& Vargas-Silva, 2017). In addition, depending on the internal regulations of the host country, refugees should be entitled to additional financial support, language classes or job trainings, which are not necessarily available for free for immigrants (Gold, 1992). Nonetheless, the state support may be counterproductive in 
making refugees more dependent on external help and less willing to take full responsibility for their life (Gold, 1988).

Another difference between immigrants and refugees, which goes in line with the disadvantage theory, is that refugees have more restricted freedom of mobility than immigrants. To some extent refugees may have influence over the country of destination (Ruiz \& Vargas-Silva, 2017); however, once they settle down in the host country and apply for asylum, their mobility may be officially limited to the borders of an administrative unit. On one hand, providing asylum-seekers with accommodation, healthcare, social security and education is a substantial burden for municipalities' budgets. Hence, the limited mobility of asylum-seekers seems to be a reasonable solution for municipalities, which invest resources in the integration of recent refugees (Godøy, 2017). On the other hand, research shows that limited mobility of refugees who live in economically poorer labor areas may have a negative impact on their remuneration even years later (Godøy, 2017). Future research should examine to what extent these findings are generalizable on the wider refugee and immigrant population (Godøy, 2017).

Last but not least, research indicates that fleeing the war zone or running away from the persecution refugees are more likely to suffer from psychological trauma than immigrants (FullerLove, Lim, \& Akehurst, 2006; Gold, 1988). On the top of that, tensions back home tend to continue in the country of asylum (Wauters \& Lambrecht, 2008).

\section{Social network theory and Transnationalism}

Social network theory focuses on the role of social relationships in setting up business activity within immigrant or refugee communities. There is no consensus in the literature on the role of social networks in the case of refugees. Some studies indicate that since refugees arrive from different destinations and do not have the ability to take part in long-term chain migration, they are less likely than immigrants to create effective social networks (Colic-Peisker \& Tilbury, 2006; Gold, 1988, 1992; Wauters \& Lambrecht, 2006a). Additionally, refugees mostly cannot go back to their country of origin and take advantage of transnational links to start a business, whereas for immigrants it is very common to import goods or mobilize money for business development in their home country (Gold, 1988; Portes, Haller, \& Guarnizo, 2002b). Other findings point out that refugees form social networks in the host country or establish transnational relationships with their home country in order to undertake entrepreneurial activities (Bizri, 2017; Omata, 2017). However, these are studies conducted in non-Western countries - Ghana and Lebanon - where there is a whole different context necessary to take into account to make further generalizations.

\section{Interactive model of ethnic entrepreneurship and Mixed embeddedness}

Waldinger with co-authors offer the interactive model of ethnic entrepreneurship, which takes into consideration the existing opportunity structure and group characteristics, in other words market opportunities and access to entrepreneurship as well as human capital and social network (Fernandez \& Kim, 1998; Kim, Hurh, \& Fernandez, 1989; R. C. Kloosterman, 2010; Waldinger, 1995). Kloosterman goes even further claiming that the development of enterprise does not take place in a socio-economic vacuum, but is determined by the political and economic context (Jones \& Ram, 2007; R. C. Kloosterman, 2010; R. Kloosterman, Van Der Leun, \& Rath, 1999; Robert Kloosterman, 2006; Robert Kloosterman \& Rath, 2010). Kloosterman introduces the concept of mixed embeddedness, which encompasses micro-level of the individual entrepreneur, meso-level of the local opportunity and macro-institutional level (R. C. Kloosterman, 2010).

The theoretical frameworks developed by Waldinger and Kloosterman within the immigrant entrepreneurship literature have been used in one of the most important studies on refugee 
entrepreneurship in order to examine why so few refugees become self-employed in Belgium (Wauters \& Lambrecht, 2008). The interactive model of ethnic business development and mixed embeddedness helped to group the obstacles refugees face when entering the entrepreneurial pathway into three variables: market opportunities and access to entrepreneurship, human capital and social networks, and institutional and societal environment (Wauters \& Lambrecht, 2008). The results show that not many refugees decide to start a small business because of lack of recognized qualifications, lack of necessary competences or insufficient funds for the start, and institutional barriers. The authors argue that these barriers are more troublesome for refugees than immigrants. Interestingly, a previous study conducted by the same researchers showed that some refugee entrepreneurs do not set up business activity to take advantage of the existing market opportunity, but to get integrated into the host society (Wauters \& Lambrecht, 2006b).

\section{CONCLUSION}

The research question I addressed in this literature review is: How does being a refugee or an immigrant affect entrepreneurial experience? The aim of the paper was to examine differences between those who were forced to flee their home country due to the fear of persecution and those who voluntary moved to another country in the light of immigrant entrepreneurship literature and emerging refugee entrepreneurship research. The search results showed that the literature on refugee entrepreneurship or their general labor market integration (145 papers) is scarce in number of applied theories and conducted studies in comparison to the immigrant entrepreneurship area (1,670 papers). In total, I have analyzed 41 peer-reviewed papers retrieved from the Scopus database. 22 papers focus on immigrant entrepreneurship, whereas 19 relate to refugees. Only 6 papers concern explicitly the topic of the refugee entrepreneurship, 2 of which refer to refugees in Ghana and Lebanon. Otherwise, the majority of papers examine the entrepreneurship or labor market integration of immigrants and refugees in the Western hemisphere. 9 studies adopted a quantitative method, 8 studies used qualitative method, 1 study applied mixed method approach and 1 paper was a policy review.

The analysis of the selected papers within the framework of the eight dominant theories - human capital, social capital, culture, disadvantage, social network, transnationalism, interactive model of ethnic entrepreneurship and mixed embeddedness - in immigrant entrepreneurship literature emerging also in the refugee related field implies that being a refugee has a rather negative impact on the entrepreneurial experience in comparison to being an immigrant. As a matter of fact, both refugees and immigrants face similar obstacles in access to the host labor market such as the lack of recognized diplomas and lack of adequate skills, which push them into an entrepreneurial pathway. Nevertheless, insufficient funds for the start of the business and institutional barriers discourage them from starting their own business. The findings of the reviewed studies argue that refugees are more likely to suffer from these barriers than immigrants.

The fundamental difference distinguishing refugees from immigrants lies in the legal status of refugees, which guarantees them a more secure stay in the host country in comparison to immigrants who are dependent on the less predictable visa regime. The legal status of an asylum-seeker or a refugee also entails other rights such as access to additional financial assistance from the state, language classes, or job trainings, which are not necessarily available for immigrants. Nonetheless, such an additional support from the state may have a dependency effect on refugees who rely more on the state support than on their own initiative. Research findings point out the phenomenon of 'refugee entry effect' or a 'refugee gap', which means that refugees suffer from a longer unemployment period due to asylum procedure. In addition, after applying for asylum, refugees may have a restricted freedom of mobility being restrained only to the borders of a certain administrative 
unit within a host country. Such a limited mobility can have a long-term effect on lower wages of refugees in their future career. There is no consensus on the role of social networks in the case of refugees, however, studies conducted on the refugees seeking asylum in the Western hemisphere imply that they are less likely to create and benefit from social networks because of two reasons. Usually they do not have the experience of long-term chain migration characteristic for immigrants and they cannot go back to their home country due to an ongoing war or fear of persecution. Last but not least, refugees who fled their home country because of war or fear of persecution are more likely than immigrants to suffer from psychological trauma, and what is more, tensions back home tend to continue in the country of asylum.

To summarize, the literature review implies that being a refugee has a rather negative impact on the entrepreneurial experience in comparison to being an immigrant. While it is possible to make general distinctions between refugees and immigrants, one needs to bear in mind that neither refugees nor immigrants constitute a homogenous group. There is great diversity among refugees depending on many factors such as, for example, their socio-economic background, country of origin, circumstances under which they left their home country etc. In light of the labor market integration or entrepreneurship discussion it is also of paramount importance where refugees apply for asylum. Even just within the EU there are so many differences between internal refugee policies that the situation of newcomers may vary from country to country (Dustmann et al., 2017). Therefore, future research should focus further on examining refugee labor market integration and their entrepreneurship in more countries bearing in mind the contextual aspects of the host countries. For this purpose, the development of the mixed embeddedness theory taking into account the micro, meso and macro level of entrepreneurship related factors seems to be a good point of departure.

\section{Literature}

Alrawadieh, Z., Karayilan, E., \& Cetin, G. (2019). Understanding the challenges of refugee entrepreneurship in tourism and hospitality. The Service Industries Journal, 39(9-10), 717-740. http://doi.org/10.1080/0264 2069.2018.1440550

Bach, R. L., \& Carroll-Seguin, R. (1986). Labor force participation, household composition and sponsorship among Southeast Asian Refugees. International Migration Review, 20(2), 381-404.

Bakker, L., Dagevos, J., \& Engbersen, G. (2017). Explaining the refugee gap: a longitudinal study on labour market participation of refugees in the Netherlands. Journal of Ethnic and Migration Studies, 43(11), 1775-1791. http://doi.org/10.1080/1369183X.2016.1251835

Bates, T. (1994). Social Resources Generated by Group Support Networks May Not Be Beneficial to Asian Immigratrant-Owned Small Businesses. Social Forces, 72(3), 671-689.

Bates, T. (1997). Financing small business creation: The case of Chinese and Korean immigrant entrepreneurs. Journal of Business Venturing, 12(2), 109-124. http://doi.org/10.1016/S0883-9026(96)00054-7

Bizri, R. M. (2017). Refugee-entrepreneurship: a social capital perspective. Entrepreneurship \& Regional Development, 5626, 1-22. http://doi.org/10.1080/08985626.2017.1364787

Bucken-Knapp, G., Fakih, Z., \& Spehar, A. (2019). Talking about Integration: The Voices of Syrian Refugees Taking Part in Introduction Programmes for Integration into Swedish Society. International Migration, 57(2), 221-234. http://doi.org/10.1111/imig. 12440

Chand, M., \& Ghorbani, M. (2011). National culture, networks and ethnic entrepreneurship: A comparison of the Indian and Chinese immigrants in the US. International Business Review, 20(6), 593-606. http://doi. org/10.1016/j.ibusrev.2011.02.009

Colic-Peisker, V., \& Tilbury, F. (2006). Employment Niches for Recent Refugees: Segmented labour Market in Twenty-first Century Australia. Journal of Refugee Studies, 19(2), 203-229. http://doi.org/10.1093/jrs /fej016

Connor, P. (2018). Explaining the Refugee Gap: Economic Outcomes of Refugees versus Other Immigrants, Journal of Refugee Studies, 23(3), 377-397. http://doi.org/10.1093/jrs/feq025

Convention Relating to the Status of Refugees, https://www.unhcr.org/1951-refugee-convention.html. 
Deakins, D., Ishaq, M., Smallbone, D., Whittam, G., \& Wyper, J. (2007). Ethnic minority businesses in Scotland and the role of social capital. International Small Business Journal, 25(3), 307-326. http://doi. org/10.1177/0266242607076530

Dheer, R. (2018). Entrepreneurship by immigrants: a review of existing literature and directions for future research. International Entrepreneurship and Management Journal, 14, 555-614. http://doi.org/10.1007/ s11365-018-0506-7

Dustmann, C., Fasani, F., Frattini, T., Minale, L., \& Schonberg, U. (2017). On the economic and politics of refugee migration. Economic Policy, (July 2017), 497-550.

Fernandez, M., \& Kim, K. C. (1998). Self-employment rates of Asian immigrant groups: an analysis of intragroup and intergroup differences. The International Migration Review, 32(3), 654-681. http://doi. org/10.2307/2547767

Fong, R., Busch, N. B., Armour, M., Heffron, L. C., \& Chanmugam, A. (2008). Pathways to Self-Sufficiency: Successful Entrepreneurship for Refugees. Journal of Ethnic \& Cultural Diversity in Social Work, 16(1-2), 127-159. http://doi.org/10.1300/J051v16n01

Frederking, L. C. (2004). A cross-national study of culture, organization and entrepreneurship in three neighbourhoods. Entrepreneurship and Regional Development, 16(3), 197-215. http://doi.org/10.1080/0898562042000197126

Fuller-Love, N., Lim, L., \& Akehurst, G. (2006). Guest editorial: Female and ethnic minority entrepreneurship, 2, 429-439. http://doi.org/10.1007/s11365-006-0007-y

Godøy, A. (2017). Local labor markets and earnings of refugee immigrants. Empirical Economics, 52(1), 31-58. http://doi.org/10.1007/s00181-016-1067-7

Gold, S. J. (1988). Refugees and small business: The case of Soviet Jews and Vietnamese. Ethnic and Racial Studies, 11(4), 411-438. http://doi.org/10.1080/01419870.1988.9993613

Gold, S. J. (1992). The employment potential for refugee entrepreneurship: Soviet Jews and Vietnamese in California. Policy Studies Review, 11(2), 176-186.

Jones, T., \& Ram, M. (2007). Re-embedding the ethnic business agenda. Work, Employment and Society, 21(3), 439-457. http://doi.org/10.1177/0950017007080007

Kim, K. C., Hurh, W. M., \& Fernandez, M. (1989). Intra-group differences in business participation: three Asian immigrant groups. The International Migration Review, 23(1), 73-95. http://doi.org/10.2307/2546183

Kloosterman, R. (2006). Mixed Embeddedness as a Conceptual Framework for Exploring Immigrant Entrepreneurship, EUREX Lecture Nr. 8.

Kloosterman, R. C. (2003). Creating opportunities. Policies aimed at increasing openings for immigrant entrepreneurs in the Netherlands. Entrepreneurship and Regional Development, 15(2), 167-181. http://doi. org/10.1080/0898562032000075159

Kloosterman, R. C. (2010). Matching opportunities with resources: A framework for analysing (migrant) entrepreneurship from a mixed embeddedness perspective. Entrepreneurship and Regional Development, 22(1), 25-45. http://doi.org/10.1080/08985620903220488

Kloosterman, R., \& Rath, J. (2010). Journal of Ethnic and Immigrant entrepreneurs in advanced economies: Mixed embeddedness further explored Immigrant entrepreneurs in advanced economies : mixed embeddedness further explored. Journal of Ethnic and Migration Studies, 9451(April 2012), 37-41. http://doi. org/10.1080/1369183002004156

Kloosterman, R., Van Der Leun, J., \& Rath, J. (1999). Mixed Embeddedness: (In)formal Economic Activities and Immigrant Businesses in the Netherlands. International Journal of Urban and Regional Research, 23(2), 252-266. http://doi.org/10.1111/1468-2427.00194

Ley, D. (2006). Explaining variations in business performance among immigrant entrepreneurs in Canada. Journal of Ethnic and Migration Studies, 32(5), 743-764. http://doi.org/10.1080/13691830600704123

Li, P. S. (2001b). Immigrants' Propensity to Self-Employment: Evidence from Canada. Social Sciences, 35(4). http://doi.org/10.1111/j.1747-7379.2001.tb00054.x

Minor, O. M., \& Cameo, M. (2018). A Comparison of Wages by Gender and Region of Origin for Newly Arrived Refugees in the USA. Journal of International Migration and Integration, 19(3), 813-828. http:// doi.org/10.1007/s12134-018-0581-1

Omata, N. (2017). Who takes advantage of mobility? Exploring the nexus between refugees' movement, livelihoods and socioeconomic status in West Africa. African Geographical Review, 6812, 1-11. http://doi.org $/ 10.1080 / 19376812.2017 .1350987$

Portes, A., Haller, W. J., \& Guarnizo, L. E. (2002a). Transnational Entrepreneurs: An Alternative Form of Immigrant Economic Adaptation Author (s): Alejandro Portes, Luis Eduardo Guarnizo and William J. Haller Published by: American Sociological Association Stable URL: http://www.jstor.org/stable/3088. American Sociological Review, 67(2), 278-298. 
Portes, A., Haller, W. J., \& Guarnizo, L. E. (2002b). Transnational Entrepreneurs : An Alternative Form of Immigrant Economic Adaptation Author (s): Alejandro Portes, Luis Eduardo Guarnizo and William J. Haller Published by: American Sociological Association Stable URL: http://www.jstor.org/stable/3088. American Sociological Review, 67(2), 278-298.

Potocky-Tripodi, M. (2004). The Role of Social Capital in Immigrant and Refugee Adaptation. Journal of Social Service Research, 31(1), 59-91. http://doi.org/10.1300/J079v31n01

Raijman, R., \& Tienda, M. (2000). Immigrants' Pathways to Business Ownership: A Comparative Ethnic Perspective. International Migration Review, 34(3), 682. http://doi.org/10.2307/2675941

Ruiz, I., \& Vargas-Silva, C. (2017). Are Refugees' Labour Market Outcomes Different from Those of Other Migrants? Evidence from the United Kingdom in the 2005-2007 Period. Population, Space and Place, 23(6). http://doi.org/10.1002/psp.2049

Sahin, M., Nijkamp, P., \& Stough, R. (2011). Impact of urban conditions on firm performance of migrant entrepreneurs: A comparative Dutch-US study. Annals of Regional Science, 46(3), 661-689. http://doi. org/10.1007/s00168-009-0351-2

United Nations Refugee Agency, https://www.unhcr.org/.

Vinogradov, E., \& Kolvereid, L. (2007). Cultural background, human capital and self-employment rates among immigrants in Norway. Entrepreneurship and Regional Development, 19(4), 359-376. http://doi. org/10.1080/08985620701223213

Waite, L. (2017). Asylum seekers and the labour market: Spaces of discomfort and hostility. Social Policy and Society, 16(4), 669-679. http://doi.org/10.1017/S1474746417000173

Waldinger, R. (1989). Structural Opportunity or Ethnic Advantage? Immigrant Business Development in New York. International Migration Review, 23(1), 48. http://doi.org/10.2307/2546182

Waldinger, R. (1995). The 'other side' of embeddedness: a case-study of the interplay of economy and ethnicity. Ethnic and Racial Studies. 18(3), 555-580. http://doi.org/10.1080/01419870.1995.9993879

Wauters, B., \& Lambrecht, J. (2006a). Refugee entrepreneurship in Belgium: Potential and practice, 509-525. http://doi.org/10.1007/s11365-006-0008-x

Wauters, B., \& Lambrecht, P. J. (2008). Barriers to Refugee Entrepreneurship in Belgium: Towards an Explanatory Model. Journal of Ethnic and Migration Studies, 34(6), 895-915. http://doi.org/10.1080/13691830802211190 